\title{
EUROPEAN EXPERIENCE OF THE METHODICAL TRAINING OF FUTURE TEACHERS OF BIOLOGY
}

\section{ЄВРОПЕЙСЬКИЙ ДОСВІД МЕТОДИЧНОЇ ПІДГОТОВКИ МАЙБУТНІХ УЧИТЕЛІВ БІОЛОГІЇ}

\section{Hrytsai Nataliia ${ }^{1}$}

DOI: http://dx.doi.org/10.30525/978-9934-571-27-5_15

\begin{abstract}
In the conditions of reforming the system of higher education in Ukraine, its integration into the European educational space, it is important to study the experience of foreign countries to introduce the best educational achievements into the practice of Ukrainian Universities. The article has been analyzed the main characteristics of methodical training of future teachers of biology in the Universities of Europe on the examples of Hungary, Republic of Poland, of Czech Republic and Slovakia, the Republic of Slovenia, the Republic of Bulgaria and Romania. The contents of biology textbooks and teaching materials have been disclosed. The leading scientists and methodologists in each country have been identified.

It was established that in Poland, during the study of "The didactics of Biology" and other disciplines of methodical direction, use of project, information and communication technologies, didactic games, micro-examination, portfolio, writing essays and essays. In the Czech Republic, more importance is attached to the use of the method of projects in schools and Universities, and in Slovakia, the introduction of digital learning technologies, a three-stage biology education model. The presence of specialized departments on didactics of biology, which successfully operate in the Universities of Poland, the Czech Republic and Slovakia, testifies to the serious attitude towards the methodological training of future biology teachers. It was found out that Hungarian biologists-methodists give great attention to the motivation in training the biology, introduction the e-learning and problem studying, using the Internet. In the Republic of Slovenia the methodical training of masters involves studying courses "The didactics
\end{abstract}

${ }^{1}$ Doctor of Pedagogical Sciences,

Professor of the Department of Biology and Medical Physiology,

Rivne State University of Humanities, Ukraine 
of biology", "The biology didactical practicum", and "The informational and communicative technologies in biology education". In Bulgaria in training the future teachers of biology apply active and interactive studying, portfolio, computer-based learning, and provide teaching "The methods of teaching the biology" and the number of other disciplines. In Romania the study of didactics the biology acquainted with such issues as problematic, computer training, group work, alternative assessment methods (projects, portfolios, self-evaluation), as well as the role of the teacher in the formal and non-formal education. The experience of European countries requires careful analysis, systematization and generalization, as well as the introduction of the best achievements in the native education.

\section{1. Ветуп}

В умовах інтеграції вищої освіти України в європейський освітній простір, впровадження нових вимог до якості підготовки майбутніх фахівців відповідно до положень Болонської конвенції корисним буде ознайомитися із сучасним станом методичної підготовки майбутніх учителів біології в країнах Європи і використовувати їхній досвід у навчальному процесі вітчизняних закладів вищої освіти. Варто погодитись із твердженнями М. Барбера та М. Муршеда про те, що «якість шкільної освіти грунтується на якості роботи вчителів, які в ній працюють» $[1$, с. 17].

Тенденції розвитку педагогічної освіти в зарубіжних країнах грунтовно досліджували Н. Авшенюк, О. Локшина, Т. Кристопчук, О. Огієнко, Н. Постригач, Л. Пуховська, А. Сбруєва та ін.

Особливості підготовки вчителів у різних країнах Європи вивчали Л. Пуховська (Західна Європа), Н. Авшенюк, В. Базуріна, І. Задорожна, А. Соколова, Н. Яцишин (Велика Британія), А. Василюк, Е. Вишневська, С. Деркач, О. Кучай, В. Пасічник (Польща), Т. П’ятакова, Л. Черток (Швейцарія), Є. Захаріна, Є. Процько (Бельгія), В. Гаманюк, А. Турчин, Л. Чулкова (Німеччина), В. Семілетко (Норвегія), Г. Кузьменко (Іспанія), О. Голотюк, О. Романенко (Франція), Л. Дзевицька (Австрія), С. Сапожников (Румунія, Болгарія, Греція) та ін. Досвід підготовки вчителів біології описано в публікаціях С. Боркача, Ш. Гала (Угорщина), М. Туленкової (Словаччина).

Проте на сьогодні виникла потреба в узагальненні та систематизації європейського досвіду методичної підготовки майбутніх учителів 
біології та впровадженні кращих його здобутків у вітчизняній педагогічній освіті.

Метою дослідження є визначення особливостей методичної підготовки майбутніх учителів біології в різних європейських країнах.

Завдання: проаналізувати навчальні плани підготовки майбутніх учителів біології в європейських університетах; визначити провідних учених-методистів та схарактеризувати їхні праці; порівняти зміст методичних дисциплін в університетах Польщі, Чехії, Словаччини, Словенії, Угорщини, Болгарії, Румунії; з'ясувати особливості методичної підготовки в кожній країні.

У ході дослідження проведено огляд літератури з проблеми дослідження, проаналізовано зміст навчальної літератури для студентів 3 методики навчання біології, опрацьовано освітні програми підготовки майбутніх учителів біології, навчально-методичне забезпечення дисципліни «Дидактика біології» та вибіркових курсів методичного спрямування різних університетів Європи, визначено прогресивні риси методичної підготовки студентів у різних країнах.

\section{2. Методична підготовка майбутніх учителів біології в Польщі}

У методичній підготовці майбутніх учителів біології в університетах Республіки Польща ключовою дисципліною $є$ «Дидактика біології».

У підручнику Вєслава Ставінського (Wiesław Stawiński) «Дидактика біології та охорони довкілля» детально розкрито основні питання, пов'язані з сучасною методикою навчання біології, природознавства і охорони навколишнього середовища, представлено приклади вирішення навчальних проблем, як з літератури так і з власних наукових досягнень і практики викладання. Книга складається 3 двох частин: у першій частині висвітлено дидактику біології та охорони довкілля як науки і предмета дослідження, особливості сучасної організації навчального процесу, розкрито нові тенденції у викладанні біології в Польщі і в світі; у другій частині описано викладання різних галузей від проблем природничої дошкільної освіти до дидактики ботаніки, зоології, фізіології, екології [14].

У Польщі в багатьох університетах створено лабораторії дидактики біології, зокрема на біологічному факультеті Варшавського університету (Uniwersytet Warszawski), на факультеті біології та охорони довкілля Сілезького університету в Катовицях (Uniwersytet Ślaski w 


\section{European experience of the methodical training of future teachers of biology}

Katowicach), на біолого-хімічному факультеті Білостоцького університету (Uniwersytet $w$ Białymstoku), на факультеті біології Гданського університету (Uniwersytet Gdański) та ін. У лабораторіях проводять заняття зі студентами, організовують освітні проекти і різні форми професійного вдосконалення вчителів.

Лігія Тушинська (Ligia Tuszyńska) - професор, завідувач лабораторії дидактики біології Варшавського університету (Uniwersytet Warszawski), автор численних праць 3 методики навчання біології та охорони довкілля [18], викладає такі дисципліни: «Дидактика біології», «Дидактика природознавства», «Дидактика вищої школи», «Оздоровча освіта», «Основи дидактики для вчителів», а також керує педагогічними практиками в початковій школі, гімназії і середній школі.

Дисципліна «Дидактика природи» («Дидактика природознавства» - Н.Г.) спрямована на студентів, які зацікавлені в отриманні права викладання природознавства в початковій школі. Під час вивчення дисципліни майбутні педагоги вчаться інтегрувати знання 3 біології, географії, фізики та хімії в блоці «природа». Основний акцент зроблено на практичних аспектах викладання (виявленню творчості в планах уроків) і методи їх оцінювання, активні форми навчання (проведення природничих експериментів, робота на місцевості), а також роль позашкільних освітніх центрів вивчення природи.

«Дидактика біології» - дисципліна для навчання студентів другого ступеня (магістратури), зацікавлених в отриманні дозволу навчати біологію в середніх школах. Курс охоплює 90 годин занять (загалом 6 кредитів ECTS), які проводяться в аудиторіях факультету біології, а також у середніх школах.

Вивчення дидактики біології спрямовано на формування компетентностей учителя біології у проведенні уроків, позакласних заходів, а також практичного застосування дидактичних засобів, методів активізації навчання, мультимедійних презентацій, біологічних експериментів, освітніх проектів та проведення освітнього вимірювання під час уроку біології в школі.

На заняттях вивчають широкий спектр стратегій, методів і форм навчання, що дають змогу планувати, реалізовувати та оцінювати проведену діяльність для третього і четвертого етапу шкільної освіти. Відомі методи та форми навчання можуть легко застосовувати в школі, пробуджуючи інтерес до біології в учнів і надихаючи їх вживати заходи 
для охорони і розвитку довкілля. У межах реалізації викладання біології студент спостерігає за уроками та проведенням навчальної діяльності, що сприяє правильному вибору методів, навчальних технологій, форм роботи та навчальних засобів.

Практичні заняття з дидактики біології виконуються відповідно до таких тем: аналіз загальної навчальної програми основної освіти для третього і четвертого етапу навчання; опрацювання навчальної програми для гімназій та ліцеїв на основі підручника учня та літератури для вчителя; правильне формулювання мети уроку; визначення стратегій навчання, методів, прийомів та форм навчання; самостійне проектування навчальних посібників; освітні вимірювання; розроблення детального плану уроку; виконання освітнього проекту як програми групової діяльності; розроблення інструкцій для проведення дослідів та лабораторних занять; підготовка учнів до біологічної олімпіади; спостереження за уроками біології та підготовка i проведення пробних уроків у середній школі, організація педагогічних досліджень.

Педагогічні практики проводяться у середніх школах в обсязі 120 годин і повною мірою готують до роботи за фахом вчителя біології [2].

У Гданському університеті (Uniwersytet Gdański) на факультеті біології працює лабораторія дидактики біології під керівництвом Рити Суски-Врубель, викладачі якої забезпечують викладання дисциплін методичного спрямування. Для студентів-бакалаврів напряму «Природознавство» в 5-6 семестрах читається «Дидактика природи», а для магістрантів напряму «Біологія» - «Дидактика біології», а також педагогічна практика. Випускники, які навчаються за програмою другого ступеня можуть працювати вчителями біології в середній школі, а студенти, які закінчили бакалаврат з напряму «Природознавство» - лише викладати природознавство у початковій школі.

Навчання біологів в магістратурі складає загалом 300 годин занять i 150 годин практики викладання, проведених у середніх школах. Студенти проходять три види практики, що відображено в навчальному плані: 1) спостереження уроків (2 семестр); 2) асистування вчителеві (3 семестр); 3) самостійне проведення занять (4 семестр). Після завершення практики студенти оформлюють портфоліо, пишуть відгук про практику [2]. 


\section{European experience of the methodical training of future teachers of biology}

У польській методиці навчання біології важливого значення надають методу проектів, електронному навчанню та формуванню цифрової компетенції.

\section{3. Методична підготовка біологів у Чехії та Словаччині}

У головному університеті Чеської Республіки - Карловому університеті в Празі функціонує кафедра навчання та дидактики біології, яка забезпечує викладання різних дисциплін методичного спрямування: «Методи і форми активізації навчання природничих предметів» ("Aktivizační metody a formy výuky přírodovědných předmětů"), «Актуальні питання викладання біології» (“Aktuální otázky ve výuce biologie”), «Вправи з дидактики біологіï» (“Cvičení z didaktiky biologie”), «Дидактичні аспекти викладання біології» (“Didaktické aspekty výuky biologie”), «Дидактика біології» (“Didaktika biologie”), «Екологічна освіта та виховання в умовах початкової та середньої школи» ("Ekologická výchova a vzdélání v podmínkách ZŠ a SŠ ”), «Екскурсії у викладанні біології та природознавства» (“Exkurze ve výuce biologie a přirodopisu”), «Міждисциплінарні зв'язки в біології» (“Mezipredmětové vztahy v biologii”), «Спостереження і експеримент у шкільній практиці» ("Pozorování a pokus ve školni praxi”), «Шкільні проекти» (“Školní projekt”), «Теорія і практика шкільних навчальних програм» (“Teorie a praxe školních vzdělávacích programй”) та ін.

Учений-біолог Мілада Швецова (Milada Švecová) досліджує методику проведення екскурсій, використання методу проектів у школі та позашкільній роботі, реалізацію міжпредметних зв'язків та інші питання дидактики біології. Крім того, науковець є автором низки наукових статей із проблеми підготовки майбутніх педагогів, зокрема про нові тенденції в методологічній підготовці вчителів біології та геології в Карловому Університеті, інновації у підготовці студентів, ефективність поєднання теорії і практики в підготовці викладачів природничих предметів, інтеграцію форм навчання як інноваційного явища у викладанні природничих дисциплін в Чеській Республіці, використання проектів у підготовці вчителів природничих дисциплін, можливості інтеграції ІКТ у навчанні природознавства та біології, роль фахової дидактики у підготовці майбутніх учителів біології та педагогічної практики [16].

М. Швецова розробила і викладає курси «Дидактика біології» (на рівні бакалавра), «Шкільні проекти», «Теорія і практика шкільних 
навчальних програм з природничих предметів», «Екологічна освіта в шкільній практиці» (на рівні магістра). Так, у змісті «Дидактики біології» передбачено вивчення таких тем: 1. Дидактика біології як наука. 2. Навчальна документація, освітні програми. Природнича освіта в межах ЄС. 3. Завдання викладання природознавства та біології на різних рівнях і в різних типах шкіл. Класифікація цілей. Встановлення освітніх завдань. 4. Підручники: функції, структурні елементи, перелік підручників, затверджених МО. 5. Методи навчання. 6. Методи активізації навчання учнів. Проблемні методи - спостереження і експеримент, методи самонавчання. 7. Класичні та сучасні засоби навчання. 8. Формування понять та створення біологічного малюнка. 9. Підготовка вчителя до уроку. 10. Проблемні завдання та їх використання в природознавстві та біології. 11. Оцінювання результатів навчання біології. Якісна і кількісна оцінка учнів з біології, дидактичні тести - варіанти і типи тестів, теорія і практика створення тестових завдань, обробка та інтерпретація результатів тестування, міжнародні програми TIMSS та PISA. 12. Екологічне виховання у біологічній освіті, виховання здорового способу життя та профілактика вживання наркотиків. 13. Організаційні форми навчання біології. Лабораторні роботи, семінари, практичні заняття та екскурсії, групові заняття, дидактичні ігри, шкільні проекти, біологічні змагання.

Тісно пов'язана $з$ чеською методичної наукою дидактика біології в Словацькій Республіці. В Університеті Коменського в Братиславі на кафедрі дидактики природничих наук, педагогіки і психології природничого факультету методичну підготовку майбутніх учителів біології забезпечено такими обов'язковими дисциплінами, як «Дидактика біології» та педагогічна практика з біології для бакалаврів, «Дидактика біології», «Техніка і методика шкільних експериментів з біології» та педагогічна практика для магістрів. Крім того, передбачено викладання багатьох цікавих вибіркових дисциплін в магістратурі, як-от: «Нові інформаційні технології в природничих науках», «Статева освіта та підготовка до шлюбу та батьківства», «Нові тенденції у викладанні предмета», «Роль учителя у профілактиці наркоманії та інших залежностей» [3] тощо.

Серед учених-методистів варто виокремити Катаріну Ушакову (Katarína Ušáková) - авторку і співавторку багатьох шкільних підручників з біології, збірників тестових завдань, численних наукових праць 
у галузі методики навчання біології, зокрема, «Основи дидактики біології» [20]. Крім того, К. Ушакова досліджувала зміст та інноваційні тенденції дидактики біології у підготовці майбутніх учителів, роль шкільних біологічних експериментів як засобу практичного навчання студентів, цифрові технології у методичній підготовці майбутніх педагогів [19] тощо.

У програмі 3 дисципліни «Дидактика біології» передбачено вивчення таких тем: «Дидактика біології як наука», «Зміст біологічної освіти», «Загальна структура підготовки вчителів до викладання», «Планування навчального процесу», «Дидактичні принципи», «Методи навчання біології», «Практичні методи викладання біології», «Формування понять у навчанні біології», «Організаційні форми викладання природознавства та біології», «Засоби навчання біології», «Робота $з$ підручником. Робота $з$ літературою та інтернет-ресурсами», «Екологічна освіта та виховання», «Перевірка результатів навчання біології та оцінювання», «Використання біологічних екскурсій $з$ урахуванням регіональних умов школи», «Міжпредметні зв’язки у навчанні біології». Варто зазначити, що в окремі теми винесено міжпредметні зв'язки, роботу з підручником та інтернет-ресурсами, біологічні екскурсії.

У Трнавському університеті у Трнаві (Trnavskej Univerzity v Trnave) в магістратурі педагогічного факультету для майбутніх учителів біології викладають дисципліну «Теорія і практика викладання біології». Програмою дисципліни передбачено вивчення таких питань: «Дидактика біології як наука», «Історія навчання біології в Словаччині», «Огляд навчального блоку - етапів навчального процесу», «Підготовка вчителів до викладання», «Завдання біологічної освіти», «Освітні стандарти, навчальні плани, державні освітні програми», «Дидактичні принципи та їхнє застосування в навчальному процесі», «Структура та зміст біологічної освіти», «Триетапна модель навчання біології», «Методи навчання», «Характеристика та використання словесних методів у навчанні біології», «Робота 3 книгою як метод навчання», «Організаційні форми навчання біології. Характеристика неформальної природничої освіти», «Засоби навчання біології», «Методи відбору та оцінювання знань і навичок з біології», «Дидактичні тести», «Природничі стежки і їх дидактичне використання у викладанні біології», «Біологічні екскурсії», «Дидактичний малюнок з біології», «Дидак- 
тична гра у навчанні біології» [3]. Таким чином, тематика курсу передбачає вивчення більш конкретних питань (дидактичні тести, природничі стежки, дидактичний малюнок, дидактичні ігри тощо).

\section{4. Методична підготовка майбутніх учителів біології в Угорщині}

У закладах вищої освіти Угорщини майбутнім учителям біології викладають такі дисципліни методичного спрямування: “A biológia tanítása” («Викладання біологіï») для рівня бакалавр (alapképzés), "A biológia tantárgypedagógiája” («Біологічна освіта»), "А biológia tantárgypedagógia legújabb eredményei” («Останні досягнення в галузі біологічної освіти») та ін. для рівня магістр, або майстер (mesterképzés).

Так, в одному з провідних ВНЗ Угорщині Дебреценському університеті (Debreceni Egyetem) в магістратурі зі спеціальності «Учитель біології» (“Biológiatanár") читається курс «Останні досягнення в галузі біологічної освіти» (лектор - доктор Іболя Ревакне-Марковці), який передбачає ознайомлення з такими актуальними проблемами:

- Розділ 1. Конструктивна педагогіка викладання біології. Мета пізнання у викладанні біології. Підручники та посібники з біології. Концепція підручника та його види. Мобільна панорама та електронні підручники. Критерії оцінювання підручників. Підручники для учнів різного віку. Робочі зошити, альбоми, практичні посібники. Збірники завдань.

- Розділ 2. Завдання теорії і практики біологічної освіти. Групи дидактичних завдань. Типи завдань 3 біології та їхня класифікація. Аналіз конкретних типів змісту і завдань з погляду педагогіки і психології. Дошка для малювання та їі роль у викладанні біології. Методика застосування мікроскопа. Типи препаратів, методика приготування.

- Розділ 3. Концепція моделі. Типи моделей. Структурні, функціональні, теоретичні та експериментальні моделі. Необхідність використання моделей. Методика моделювання. Застосування методичних моделей.

- Розділ 4. Використання комп'ютерів у навчанні біології. Комп'ютер як наочний посібник. Умови і можливості PowerPoint. Інтернет-додатки. Е-проекти. Електронне навчання. Співпраця. Перевірка знань з біології. Рейтинг з біології у класі. Оцінювання методів навчання біології. Можливості наукових досліджень. Вимірювання ефективності методів навчання біології у класі. «Лісова школа», зоопедагогіка, музейна педагогіка [3]. 


\section{European experience of the methodical training of future teachers of biology}

В Університетському коледжі Ніредьгаза в Інституті біології факультету природничих наук та інформаційних технологій готують учителів біології на рівні бакалавра. Під час вивчення курсу «Спеціальна методика» (“Szakmódszertan"), розробленого Мартою Тот Доброни (Dobróné Dr. Tóth Márta), студенти засвоюють такі теми: методика навчання біології (концепція, предмет, вимоги до навчання біології, знання матеріалу); конкретні завдання викладання біології у формуванні особистості; методи викладання та навчання; спеціальні мотиваційні можливості викладання біології, розвиток пізнавальних навичок; документи, які використовують у викладанні біології; засоби навчання біології; моніторинг продуктивності учнів і оцінювання; роль спостережень та експериментів у біологічній освіті; форми організації навчання біології; організаційні та методичні питання позакласних заходів з біології; методи викладання біології в класі; методи педагогічної діяльності: демонстрації, лекції, пояснення, розповідь, контроль, оцінювання ефективності. Майбутні учителі аналізують плани і програми, складають плани уроків, проектів, готують мультимедійні презентації, самостійно опрацьовують навчально-методичну літературу. Учительська практика студентів триває упродовж цілого семестру [3].

Серед угорських біологів-методистів варто назвати таких науковців, як Іштван Кочур (István Kacsur), Геза Добо (Géza Dobó), Дьордь Фозекош (György Fazekas), Єва Боджар (Éva Bodzsár), Ірен Бекафi (Irén Békefi), Іболя Ревакне-Марковці (Ibolya Revákné-Markóczi) та ін.

Так, у книзі Дьордя Фозекоша висвітлено наукове дослідження проблем біологічної освіти [9]. Угорський вчений Геза Добо є автором численних посібників з методики навчання біологіï, зокрема "A biológia tanítása" [7], "A biológia tantárgypedagógiája” [8] та ін.

У низці видань книги "A biológia tanítása” за редакцією Іштвана Кочура розкрито зміст і структуру викладання біології, схарактеризовано методи навчання, вказано особливості групових та індивідуальних робіт, описано методику контролю знань та критерії оцінювання, сутність виховної роботи вчителя. Окрему увагу приділено методиці викладання різних розділів біології, зокрема цитології, екології, генетики, еволюційного вчення та ін. [11].

Досить цінним є сучасний посібник 3 методики навчання біології "Kézikönyv a biológiatanítás módszertanához" за редакцією Єви Боджар, 
у якому висвітлено такі питання: методологія навчання біології, методика навчання біології як наука та її зв'язки з іншими дисциплінами; мотивація у викладанні біології; зміст біологічної освіти; планування уроків біології; організаційні форми навчання біології; позакласна діяльність з біології; екологічна освіта у викладанні біології; методи і засоби викладання біології; використання підручника біології та іншої навчальної літератури; застосування мережі Інтернет у навчанні біології; контроль знань учнів з біології [6] тощо.

\section{5. Методична підготовка майбутніх учителів біології в Республіці Словенія}

Майбутніх учителів біології в Словенії готують на факультеті природничих наук та математики Університету м. Марибор (Univerza v Mariboru). Для студентів магістратури кафедрою дидактики біології забезпечено викладання таких дисциплін методичного спрямування: «Дидактика біології» (“Didaktika biologije”), «Практикум з дидактики біології» ("Biološki didaktični praktikum”), «ІКТ в біологічній освіті» (“IKT v biološkem izobraževanju”), «Наставництво в позакласній діяльності» ("Mentorstvo obšolskim dejavnostim”) та проведення педагогічної практики. Лектором є Андрей Шорго (Andrej Šorgo), який керує кафедрою дидактики біології і досліджує інформаційно-комунікаційні технології навчання [13].

У ході методичної підготовки студенти під час навчання на лекціях ознайомлюються $з$ теоретичними основами професії вчителя, під час лабораторних занять випробовують себе в ролі вчителя, використовують різні методи навчання, виконують лабораторні експерименти, досліди 3 живими організмами, проводять тестування та оцінювання умінь та навичок, а потім перевіряють свої знання та вміння в безпосередньому контакті з учнями.

Навчальним планом магістратури на дисципліну «Дидактика біології» передбачено 7 кредитів ECTS: 30 год. - лекцій, 15 год. - семінари, 45 год. - лабораторні роботи, 120 год. - самостійна робота.

На лекціях розглядають такі питання: предмет дидактики біології; зв'язок між загальною та спеціальною дидактикою; специфіка дидактики біології та методики викладання біології; моделі викладання біології в Словенії та світі; навчальні плани та навчальні програми змістових ліній з біології у початковій і середній школі; модель педагогічного 


\section{European experience of the methodical training of future teachers of biology}

змісту і технічні знання; компетенції в галузі освіти; планування уроку, постановка цілей, стратегія викладання і навчання; дидактичні принципи; методи роботи в класі; форми навчання; перевірка та оцінювання роботи школи; дослідно- і проблемно-орієнтоване навчання; навчальні посібники та обладнання; ІКТ в освіті; навчання еволюції; соціально-природничі теми; дослідницька діяльність; робота в класі.

Лабораторні вправи передбачають практичну роботу майбутніх учителів: підготовку планів уроків, розроблення навчальних посібників, методичних матеріалів, виготовлення пристроїв, презентацій, а також мікровикладання.

На вивчення дисципліни «Практикум 3 дидактики біології» передбачено 12 кредитів на 2 семестри. На заняттях студенти освоюють методи лабораторних і практичних робіт, проводять дидактичні біологічні експерименти, планують лабораторні та експериментальні роботи, вивчають правила техніки безпеки під час роботи, застосовують ІКТ в лабораторних і польових роботах, вчаться оцінювати лабораторні та експериментальні роботи, працюють 3 живими організмами, обслуговують віварії, самостійно проводять лабораторні роботи у вигляді мікровикладання [3].

У найбільшому державному університеті - Люблянському (Univerza $v$ Ljubljani) на педагогічному факультеті готують учителів двох предметів, як-от: біологія-хімія, біологія-фізика, біологія-домогосподарство, біологія-техніка.

Для них викладають дисципліну «Дидактика біології», на яку передбачено 19 кредитів: 90 год. лекцій, 15 год. семінарів, 15 год. практичних, 60 год. лабораторних, 45 год. практичної підготовки, 60 год. педагогічної практики і 285 год. самостійної роботи. Крім того, цікавими є курси «Дидактика з основами ІКТ», «Педагогічна методологія» та ін.

Для викладання в гімназіях студенту потрібно закінчити програму навчання другого ступеня - магістратуру, де передбачено викладання таких дисциплін методичного спрямування, як «Вибрані розділи біології з дидактикою» (“Izbrana poglavja biologije z didaktiko”), «Позашкільні заняття з біології» ("Pouk biologije izven šole" - дослівно «Навчання біологї за межами школи») та «Екологічна освіта» (“Okoljsko izobraževanje”).

Викладання дидактики біології та методично орієнтованих дисциплін забезпечують Грегор Торкар (Gregor Torkar) і Слка Стргар 


\section{Hrytsai Nataliia}

(Jelka Strgar). Г. Торкар проводить наукові пошуки у галузі екологічної освіти, освіти для сталого розвитку, охорони природи, вивчає ставлення майбутніх учителів до природи, роль педагога в природоохоронній діяльності, вплив цінностей учителя на освітню і виховну роботу 3 охорони природи [17]. Є. Стргар досліджує проблеми підвищення інтересу студентів до біології, мотивацію навчально-пізнавальної діяльності, а також методику вивчення клітинного циклу, властивостей живих систем та інших тем у середній школі [15].

На біотехнічному факультеті Люблянського університету готують учителів-біологів за педагогічною магістерською навчальною програмою другого ступеня «Біологічна освіта» (“Biološko izobraževanje”). Навчання триває два роки і становить 120 кредитів. Мета програми підготовки - виховання біологічно та педагогічно висококваліфікованого і мотивованого вчителя біології, який відповідатиме на виклики часу під час викладання біології в гімназіях, а також у середніх технічних і професійних школах.

Упродовж 1-3 семестрів вченими-методистами Єлкою Стргар (Jelka Strgar) і Ізтоком Томажичем (Iztok Tomažič) для студентів-біологів читається основна дисципліна методичного спрямування - «Дидактика біології», на яку винесено 16 кредитів: 105 год. лекцій, 45 год. семінарських занять, 65 год. лабораторних занять, 15 год. польових робіт, 250 год. самостійної роботи.

Основні питання курсу: важливість та використання живих організмів у навчанні біології (вирощування і догляд за живими істотами в штучному середовищі, вироблення позитивного ставлення до живих організмів, правила безпеки та етичні стандарти у використанні живих організмів у процесі навчання); форми навчально-виховної роботи; основні методи і прийоми навчально-виховної роботи; засоби навчання (підручники та робочі зошити з біології, аудіо-візуальні засоби, інформаційно-комунікаційні технології у навчанні біології); навчальні плани та програми з біології; основи конструювання навчального процесу (річне і тематичне планування, класифікація і таксономія знань, актуальних для шкільної простору (Блум, Марзано, Віггінс), адаптація змісту освіти до цільової групи учнів); реалізація навчального процесу (використання відповідних форм і методів роботи, управління навчальним процесом у різних ситуаціях і на різних рівнях освіти); оцінювання навчального процесу (методи контролю навчання, пере- 
вірка та оцінювання знань, самооцінювання); методика проведення лабораторних робіт, біологічного експерименту та польових робіт; педагогічні дослідження; шкільна документація; система освіти в Словенії та зарубіжних країнах [3].

Під час навчання упродовж двох років проводять педагогічну практику в початковій і середній школі, під час якої студенти спостерігають за проведенням уроків учителем-наставником, допомагають йому організовувати навчальний процес, знайомляться зі шкільною документацією, готують, проводять і оцінюють власні заняття та формують портфоліо педагогічної практики. Оцінюють практику після публічного захисту портфоліо.

\section{6. Методична підготовка біологів в університетах Болгарії та Румунії}

Результати наукового пошуку дають підстави стверджувати, що в Болгарії є багато фахівців, наукова спеціальність яких - «методика навчання біології». Серед них - Наташа Цанова, Надєжда Райчева, Грозданка Ставрева, Снєжана Томова, Ася Асьонова, Свєтлана Ангелова, Єлка Радославова та ін.

Серед сучасних болгарських учених-методистів вважаємо за доцільне виокремити Наташу Цанову та Надєжду Райчеву (Софійський університет «Св. Климент Охридський»), авторів праці «Методика на обучението по биология - теория и практика» («Методика навчання біології - теорія і практика»). У монографії розкрито загальну концепцію методики викладання біології як науки та навчальної дисципліни у вищій школі, представлено теоретичні ідеї та технології вирішення основних проблем методики викладання біології: модель фахівця учителя біології; завдання навчання біології; біологічна освіта в середній школі; вибір і структурування навчального матеріалу; навчальний процес з біології - системний аналіз, мотиви і мотивація, алгоритмізація процесу, навчальні задачі з біології, форми організації, методи навчання; контроль у процесі навчання біології; теорії навчання, зміст навчальних предметів «Людина і природа» та «Біологічна і валеологічна освіта» [5].

Цінним також $є$ підручник з методики навчання біології Грозданки Ставревої (Пловдійський університет «Паїсій Хилендарський»), у якому вибрано, систематизовано, доповнено й узагальнено теоретичні 
та прикладні досягнення з методики навчання біології, що становлять теоретичну основу професійно-педагогічної підготовки студентів майбутніх учителів біології. Зміст складається з трьох частин, 6 розділів та тематичних комплексів: частина перша «Bcmуn у методику навчання біології»: «Розділ 1. Виникнення та історичний розвиток методики навчання біології», «Розділ 2. Методика навчання біології як наука»; частина друга «Теорія навчання біології. Методологія»: «Розділ 3. Методологічні основи», «Розділ 4. Компоненти системи навчання біології. Методичні поняття системи», «Розділ 5. Теорія біологічної освіти»; частина третя «Теорія навчання біологї-стратеziї $і$ технологї̈»: «Розділ 6. Організаційні системи і форми навчання в біології». В підручнику методична наука і дисципліна розглядається як триєдина модель «методологія - стратегія - технології», що, на думку автора, є моделлю прогресивного розвитку методики навчання [4].

У Софійському університеті «Св. Климент Охридський» впроваджено бакалаврську і магістерську програму за спеціальністю «Учитель біології з викладанням англійською мовою». Бакалаврам викладають обов'язкові дисципліни «Методика навчання біології» i «Методика i техніка навчального експерименту з біології», а серед вибіркових дисциплін - «Електронне і дистанційне навчання в біологічній освіті», «Позакласна робота з біології», «Екологічна освіта і виховання», «Прикладна психологія в біологічній освіті». Магістрантам запропоновано такі обов'язкові дисципліни методичного модуля: «Інноваційні технології навчання біології», «Міжпредметні зв'язки у навчанні біології», «Управління якістю біологічної освіти в середній школі», «Педагогічне конструювання та комп'ютерні технології у навчанні біології».

У Румунії методична підготовка майбутніх учителів біології реалізується в ході вивчення модуля педагогічних дисциплін. Так, студенти, які виявили бажання освоїти професію вчителя біології, укладають угоду з відділом підготовки вчителів (departamentul pentru pregatirea personalului didactic) університету і факультативно вивчають дисципліни педагогічного модуля, зокрема «Дидактику спеціальності» («Дидактику біології»).

У найбільшому вищому навчальному закладі Румунії - Яському університеті імені А. Й. Кузи (Universitatea Alexandru Ioan Cuza din Iaşi) на біологічному факультеті для бакалаврів-біологів виокремлено факультативний педагогічний модуль обсягом 30 кредитів, до якого входить 


\section{European experience of the methodical training of future teachers of biology}

педагогіка, педагогічна психологія, дидактика спеціальності, курси за вибором та педагогічна практика. Варто зазначити, що планом визначено також підсумкове оцінювання дидактичного портфоліо студента.

Програмою дисципліни «Дидактика спеціальності» передбачено розгляд таких загальних тем: навчальний план та його структура, шкільний підручник, проектування навчання, урок як основна форма організації навчання, структура і типи уроків, традиційний і сучасний урок, аналіз і оцінювання уроків, навчання через дослідження і відкриття, методи навчання, організація навчання в малих групах, кооперативне навчання, стратегії навчання, засоби навчання, оцінювання, дидактичні принципи тощо.

У Клузькому університеті імені Бабеша-Бойяї (Universitatea BabeşBolyai Cluj-Napoca) на факультеті біології та геології також готують майбутніх учителів біології за контрактом. «Програма психопедагогічного навчання» розрахована на 30 кредитів і охоплює такі дисципліни, як психологія навчання, педагогіка (загальна педагогіка, теорія і методологія навчальних програм, теорія і методологія навчання, теорія і методологія оцінювання), дидактика спеціальності, комп'ютерне навчання, робота класного керівника, які викладають упродовж шести семестрів, та педагогічну практику.

У Західному університеті Тімішоари (Universitatea de Vest din Timisoara) на факультеті хімії, біології та географії для бакалаврів курс дидактики біології викладає Ніколета Яновічі (Nicoleta Ianovici). Варто зупинитися на іiі посібнику «Дидактика біології - лекційний курс і семінари», в якому докладно розкрито зміст дисципліни [10]. У книзі висвітлено такі теми:

Розділ 1. Вимоги до навчальної роботи. Навчальні компетенції. Навчальні комунікації. Стилі навчання. Мотиваційні аспекти у навчальній роботі. Короткий психологічний маршрут. Конкуренція $\mathrm{i}$ співпраця. Мистецтво мотивації. Профіль учителя біології.

Розділ 2. Курикулум. Процес освіти в Румунії. Навчальний план і реформа. Національний курикулум. Планування в освіті. Цілі освіти. Навчальні програми. Програми для гімназій. Програми для ліцеїв. Шкільні підручники. Застосування дидактичних принципів у проектуванні викладання та навчання біології.

Розділ 3. Навчальні технології. Методологія дидактики. Специфічні методи біології: експозиція, словесні, спостереження, метод 
демонстрації, експеримент, метод практичної роботи, навчання через відкриття, проблематизація (проблемно-орієнтоване навчання), моделювання, алгоритмізація, комп'ютерне навчання, інтерактивні методи. Засоби навчання.

Розділ 4. Педагогічне проектування. Сутність педагогічного проектування. Педагогічне проектування в сучасній дидактиці. Поняття освітньої (навчальної) одиниці. Процесуальний алгоритм у проектуванні навчальних модулів. Проектування одиниці змісту (уроку). Послідовність календарного планування. Проекти для навчальних одиниць.

Розділ 5. Оичінювання роботи школи залежно від навчальних иุілей. Функції оцінки. Види оцінювання. Альтернативні методи оцінювання (систематичне спостереження за діяльністю і поведінкою учнів, проект, есе, портфоліо, самооцінювання). Побудова тестів. Успішність школярів.

Розділ 6. Учитель біології та його роль у формальній $і$ неформальній освіті. Роздуми про значення вчителів у суспільстві. Від екологічної освіти до освіти для сталого розвитку. Класна година.

Розділ 7. Організачія та проведення педагогічної практики. Журнал педагогічної практики з документами, підготовленими студентами-практикантами. Документація діяльності, яка допомагала в педагогічній практиці. Документація виконаної діяльності. Портфоліо практики [10].

В Університеті м. Орадя (Universitatea din Oradea) на факультеті наук (Facultăţii de Ştiinţe) «Дидактику біологіï» для майбутніх учителів викладає Маріана Марінеску (Mariana Marinescu), автор численних праць 3 методики навчання біології та посібника «Дидактика біології. Теорія і практика» [12]. Ця робота є джерелом інформації не лише для науково-педагогічної підготовки студентів-біологів і захисту довкілля, але й для вдосконалення вчителів-практиків.

Румунські вчені активно впроваджують альтернативні стратегії навчання (проблемне, проектне, евристичне, комп’ютерне навчання) i стверджують про їхню більшу ефективність порівняно із традиційним навчанням.

\section{7. Висновки}

Методична підготовка майбутніх учителів біології в університетах різних країн Європи має свої особливості. Так, у Польщі підготовка студентів має практико орієнтований характер. Під час вивчення 


\section{European experience of the methodical training of future teachers of biology}

«Дидактики біології» та інших дисциплін методичного спрямування використовують проектні та інформаційно-комунікаційні технології, дидактичні ігри, мікровикладання, виготовлення портфоліо, написання рефератів та есе тощо.

В університетах Чеської та Словацької Республіки студенти ознайомлюються з методами активізації навчальної діяльності учнів, проблемним і проектним навчанням, дослідницько-орієнтованим навчанням, методикою проведення екскурсій, організацією біологічних експериментів, використанням мультимедійних технологій та іншими сучасними проблемами дидактики біології. У Чехії більше значення надають використанню екскурсій і методу проектів у школі та університеті, а в Словаччині - впровадженню цифрових технологій навчання, триетапної моделі навчання біології.

Для угорських учених-методистів актуальними $є$ дослідження мотивації навчальної діяльності, використання навчальних проектів, реалізації проблемного підходу, впровадження особистісно- та дослідно-оріснтованого навчання, комп'ютерних технологій, основних засад екологічної освіти тощо.

У Словенії важливе місце відводять ознайомленню майбутніх учителів біології з інформаційно-комунікаційними технологіями, дослідницькою діяльністю, методикою використання живих організмів у навчанні біології.

Болгарські науковці важливе значення надають педагогічній практиці студентів, а також пропонують застосовувати у підготовці майбутніх учителів біології інноваційні технології: проектне навчання, навчання через співпрацю, інтерактивне навчання, портфоліо, комп'ютерно орієнтоване навчання.

У Румунії під час вивчення дидактики біології детально ознайомлюються з проблемним, комп'ютерним навчанням, методикою організації групової роботи учнів, альтернативними методами оцінювання (зокрема портфоліо). У навчальних планах румунських університетів відведено 30 кредитів на викладання факультативного педагогічного модуля.

Таким чином, кожна країна має свої особливості методичної підготовки майбутніх учителів біології. Українським ученим і викладачам необхідно грунтовно вивчити досвід зарубіжних країн і впроваджувати кращі здобутки у вітчизняних закладах вищої освіти. Особливу увагу 


\section{Hrytsai Nataliia}

варто приділити організації дослідницько-орієнтованого навчання, застосуванню інформаційно-комунікаційних технологій, захисту студентами методичних проектів, портфоліо практики тощо.

Перспективи подальших досліджень полягатимуть у вивченні досвіду підготовки майбутніх учителів біології в університетах інших країн.

\section{Список літератури:}

1. Барбер М., Муршед М. (2008). Как добиться стабильно высокого качества обучения в школах. Уроки анализа лучших систем школьного образования мира. Вопросы образования, № 3, С. 7-60.

2. Грицай Н. Б. (2017). Методична підготовка майбутніх учителів біології в університетах Польщі та України: компаративний аналіз. Development and modernization of social sciences: experience of Poland and prospects of Ukraine : Collective monograph. Vol. 1. Lublin : Izdevnieciba "Baltija Publishing", p. 116-133.

3. Грицай Н. Б. (2016). Теорія і практика методичної підготовки майбутніх учителів біології : монографія. Рівне : О. Зень.

4. Ставрева Г. (2010). Методика на обучението по биология : учебник. Пловдив : Университетско издателство «Паисий Хилендарски».

5. Цанова Н., Райчева Н. (2012). Методика на обучението по биология теория и практика. София : Pensoft.

6. Bodzsár É. (2005). Kézikönyv a biológiatanítás módszertanához / szerk. Szeged : Trefort.

7. Dobó G. (1979). A biológia tanítása. Budapest : Tankönyvkiadó.

8. Dobó G. (1994). A biológia tantárgypedagógiája : tanárképző föiskola. Budapest : Nemzeti Tankönyvkiadó.

9. Fazekas G. (1975). A biológia-tanítás tudományos vizsgálata (1960-1974). Budapest : Tankönyvkiadó.

10. Ianovici N. (2006). Didactica Biologiei - suport de curs şi seminar. Timişoara : Ed. Mirton.

11. Kacsur I. (1987). A biológia tanítása. Budapest: Tankönyvkiadó.

12. Marinescu M. (2010). Didactica biologiei. Teorie și aplicații. Piteşti : Editura Paralela 45.

13. Šorgo A. Verčkovnik T., Kocijančič S. (2010). Information and Communication Technologies (ICT) in Biology Teaching in Slovenian Secondary Schools. Eurasia Journal of Mathematics, Science \& Technology Education, no $6(1)$, ss. 37-46.

14. Stawiński W. (2006). Dydaktyka biologii i ochrony środowiska. Warszawa: Wydawnictwo Naukowe PWN.

15. Strgar J. (1998). Motivacija obiskovalcev kot izhodišče za pedagoško delo $\mathrm{v}$ Botaničnem vrtu Univerze $\mathrm{v}$ Ljubljani (PhD Thesis). Ljubljana : Univerza $\mathrm{v}$ Ljubljani.

16. Švecová M., Stoklasa J., Borůvkova J., Šulcová R. (2001). Projects and Teaching Practice in Training Teachers of Natural Science Disciplines at the Charles 


\section{European experience of the methodical training of future teachers of biology}

University of Prague. Matthias Belivs University Proceedings, Faculty of Natural Sciences. Banská Bystrica : Univerzita Mateja Bela. Vol. 1. № 1. pp. 13-24.

17. Torkar G. (2006). Vplivi učiteljevih vrednot na njegovo vzgojno izobraževalno delovanje na področju varstva narave ( $\mathrm{PhD}$ thesis). Ljubljana: Univerza v Ljubljani.

18. Tuszyńska L. (2005). Metodyka nauczania biologii i ochrony środowiska : dla studentów i nauczycieli przedmiotów przyrodniczyc. Warszawa: Wydawnictwa Uniwersytetu Warszawskiego.

19. Ušáková K. (2013). Digitálne technológie a didaktická príprava budúcich učitel'ov. Priority terciálneho vzdelávania učitel'ov prírodoved ných, polnohospodárskych a príbuzných odborov. Nitra : FPV UKF, ss. 42-47.

20. Ušáková K. (1990). Základy didaktiky biológie. Bratislava: Univerzita Komenského.

\section{References:}

1. Barber M., Murshed M. (2008). Kak dobit'sya stabil'no vysokogo kachestva obucheniya v shkolakh. Uroki analiza luchshikh sistem shkol'nogo obrazovaniya mira [How to achieve consistently high quality of education in schools. Lessons from the analysis of the best systems of school education in the world]. Voprosy obrazovaniya [Education issues], no 3, pp. 7-60. (in Russian).

2. Hrytsai N. B. (2017). Metodychna pidhotovka maibutnikh uchyteliv biolohii v universytetakh Polshchi ta Ukrainy: komparatyvnyi analiz [Methodical preparation of future teachers of biology at the universities of Poland and Ukraine: comparative analysis]. Development and modernization of social sciences: experience of Poland and prospects of Ukraine : Collective monograph. Vol. 1. Lublin: Izdevnieciba "Baltija Publishing", pp. 116-133. (in Ukrainian).

3. Hrytsai N. B. (2016). Teoriia i praktyka metodychnoi pidhotovky maibutnikh uchyteliv biolohii [Theory and practice of methodical preparation of future teachers of biology]: monograph. Rivne: O. Zen. (in Ukrainian).

4. Stavreva G. (2010). Metodika na obucheniye po biologia [Methods of teaching biology]: uchebnik [textbook]. Plovdiv: Universitetsko izdatelstvo "Paisiy Khilendarski", (in Bulgarian).

5. Tsanova N., Raycheva N. (2012). Metodika na obucheniye po biologia teoriya i praktyka [Methods of teaching biology - theory and practice]. Sofiya: Pensoft. (in Bulgarian).

6. Bodzsár É. (2005). Kézikönyv a biológiatanítás módszertanához / szerk. Szeged: Trefort.

7. Dobó G. (1979). A biológia tanítása. Budapest: Tankönyvkiadó.

8. Dobó G. (1994). A biológia tantárgypedagógiája: tanárképző főiskola. Budapest: Nemzeti Tankönyvkiadó.

9. Fazekas G. (1975). A biológia-tanítás tudományos vizsgálata (1960-1974). Budapest: Tankönyvkiadó.

10. Ianovici N. (2006). Didactica Biologiei - suport de curs şi seminar. Timişoara: Ed. Mirton.

11. Kacsur I. (1987). A biológia tanítása. Budapest: Tankönyvkiadó. 
12. Marinescu M. (2010). Didactica biologiei. Teorie și aplicații. Piteşti: Editura Paralela 45.

13. Šorgo A. Verčkovnik T., Kocijančič S. (2010). Information and Communication Technologies (ICT) in Biology Teaching in Slovenian Secondary Schools. Eurasia Journal of Mathematics, Science \& Technology Education, № 6 (1), ss. 37-46.

14. Stawiński W. (2006). Dydaktyka biologii i ochrony środowiska. Warszawa: Wydawnictwo Naukowe PWN.

15. Strgar J. (1998). Motivacija obiskovalcev kot izhodišče za pedagoško delo v Botaničnem vrtu Univerze v Ljubljani ( $\mathrm{PhD}$ thesis). Ljubljana: Univerza v Ljubljani.

16. Švecová M., Stoklasa J., Borůvkova J., Šulcová R. (2001). Projects and Teaching Practice in Training Teachers of Natural Science Disciplines at the Charles University of Prague. Matthias Belivs University Proceedings, Faculty of Natural Sciences. Banská Bystrica: Univerzita Mateja Bela, Vol. 1, № 1, pp. 13-24.

17. Torkar G. (2006). Vplivi učiteljevih vrednot na njegovo vzgojno izobraževalno delovanje na področju varstva narave (PhD thesis). Ljubljana: Univerza v Ljubljani.

18. Tuszyńska L. (2005). Metodyka nauczania biologii i ochrony środowiska: dla studentów i nauczycieli przedmiotów przyrodniczyc. Warszawa: Wydawnictwa Uniwersytetu Warszawskiego.

19. Ušáková K. (2013). Digitálne technológie a didaktická príprava budúcich učitel'ov. Priority terciálneho vzdelávania učitel'ov prírodoved ných, pol'nohospodárskych a príbuzných odborov. Nitra: FPV UKF, ss. 42-47.

20. Ušáková K. (1990). Základy didaktiky biológie. Bratislava : Univerzita Komenského. 